Ballesteros, T., Tubío, A., Rodríguez, R., Hernández, A., Costas, D., \& Troncoso, J. (2021). Reproductive cycle of the sea cucumber Holothuria forskali (Holothuriida: Holothuriidae) in the Ría de Vigo (NW of Spain). Revista de Biología Tropical, 69(S1), 101-117. DOI 10.15517/rbt.v69iSuppl.1.46331

DOI 10.15517/rbt.v69iSuppl.1.46331

\title{
Reproductive cycle of the sea cucumber Holothuria forskali (Holothuriida: Holothuriidae) in the Ría de Vigo (NW of Spain)
}

\author{
Tania Ballesteros ${ }^{1 *}$ \\ Ana Tubío ${ }^{1}$ \\ Rosana Rodríguez ${ }^{2}$ \\ Alba Hernández ${ }^{1}$ \\ Damián Costas ${ }^{2}$ \\ Jesús Troncoso ${ }^{1}$
}

1. Centro de Investigación Mariña, Universidade de Vigo, Grupo de Ecoloxía Costeira, Edificio CC Experimentais, Campus Lagoas Marcosende, Vigo, Spain; tballesteros@uvigo.es (*Correspondence), atubio@uvigo.es, alba.hernandez@uvigo.es, troncoso@uvigo.es

2. Centro de Investigación Mariña, Universidade de Vigo, Estación de Ciencias Mariñas de Toralla, Illa de Toralla, Coruxo,Spain; rrodriguez@uvigo.es,dcostas@ecimat.org

Received 10-V-2020. Corrected 08-IX-2020. Accepted 20-X-2020.

\begin{abstract}
Introduction: The exploitation of the sea cucumber (Holothuria (Panningothuria) forskali) in Ría de Vigo (NW Spain) is recent (2015) and it has been done until now with scarce or no information about some key biological aspects as reproduction, recruitment or growth. Objective: To describe the reproductive cycle of $H$. forskali in Ría de Vigo. Methods: We sampled fortnightly throughout 2018. We calculated gonadal condition indices (GCI) and gametogenic stages by classic histological methods. Results: The reproductive cycle of $H$. forskali in the Ría de Vigo is characterized by a sexual resting stage during spring, when temperature and daylight hours are lower; the beginning of gametogenesis during summer, when temperature is higher, daylight hours longer and the sea bottom is rich in nutrients; then, a period of spawns interspersed with a gonadal restoration during autumn and winter, when temperature is lower and food is scarce. Sex ratio is $1: 1$, however, the studied population is not synchronized, because females initiate maturation earlier. The comparison of the histological results with GCI indices suggest that GCI is a good indicator for gonadal stage. Fishery management strategies, such as a closure period, must be adapted to the reproductive stage. We recommend avoiding fishing between November and February to increase spawning potential ratio and, consequently, recruitment.
\end{abstract}

Key words: gonad restoration; abiotic factors; sex ratio; gonadal condition index; fisheries.

For centuries, sea cucumbers have been consumed as a luxury food item in Asian countries (Conand \& Byrne, 1993; Bordbar, Anwar \& Saari, 2011; Mehmet, Hüseyin, Bekir, Yilmaz \& Sevim, 2011; Purcell et al., 2013) due to its high protein content, low fat content and amino acid profile (Chen, 2003, 2004; Taboada,
Millán, Míguez \& Fernández-Pulpeiro, 2008). Due to its nutritional richness, they have also been used in artificial feed (Bakus, 1973) and as a fishing bait (Entrambasaguas, 2008). They have been used in the traditional medicine systems, too because of their effectiveness against hypertension, asthma, rheumatism, cuts and 
burns, impotence and constipation (Wen, $\mathrm{Hu} \&$ Fan, 2010; Bordbar et al., 2011). Also, they are part of balms, oils, toothpastes, body lotions and soaps (Poh-Sze, 2004; Conand, 2005). In addition, new studies have attracted interest from nutritionists and pharmacologists (Zhong, Khan \& Shahidi, 2007; Bordbar et al., 2011; Santos et al., 2016).

All these possible applications have massively increased their demand, causing serious problems of overexploitation around the world. The high demand has caused $70 \%$ of the fisheries to be depleted or over/fully exploited, and that has led to the search for new less valuable species in other distribution areas (Guzmán, Guevara \& Hernández, 2003; Purcell et al., 2013; Sonnenholzner, Searcy-Bernal \& Panchana-Orrala, 2017; González-Wangüemert, Domínguez-Godino \& Cánovas, 2018). 16 out of the 66 exploited species have been classified as vulnerable or endangered by IUCN (Conand et al., 2014; IUCN, 2019).

One of these new target species is Holothuria (Panningothuria) forskali (GonzálezWangüemert et al., 2018). This species is present in the NE Atlantic Ocean, in Portugal several companies are selling it (GonzálezWangüemert, Valente, Henriques, DomínguezGodino \& Serrão, 2016) and in Galicia (NW of Spain) it began being exploited in 2015 . Galicia's fisheries are co-managed by the Autonomous Administration (Xunta de Galicia) and fisher's guilds (called "cofradías de pescadores") which nowadays design harvesting plans every three years. H. forskali was included in the sea urchin exploitation plan (Plan Xeral de Explotación, 2015), as both are echinoderms. Until now, the management of the exploitation of this marine resource has been done with scarce or no information about some key biological aspects as reproduction, recruitment and growth in this area. Studies about the reproduction of holothurians are usually implemented when a fishery exploitation has already started, or even when populations are already overexploited (Navarro, GarcíaSanz \& Tuya, 2012).
There are only two studies on the reproductive biology of this species. The first one was carried out in Brittany-France by Tuwo and Conand (1992) and the second in PenichePortugal (2016) by Santos et al. Both agree that it has an annual cycle, but disagree on other aspects such as the resting period. The gametogenic cycle may differ between populations in response to interactions with external factors (e.g. seawater temperature, salinity, light, food availability, parasitic infestations) and internal factors (e.g. genetics, hormonal cycle, nutrient reserves). This may generate variations even within a small spatial range like a ria, especially in sedentary invertebrates such as sea cucumbers. In a study of gonadal development of the temperate species Sewell (1992) found that one population in northern New Zealand had complete resorption of the gonad after spawning, with no gonad material present during the winter months. The same species in the south retained a large volume of tubules containing developing oocytes in the resting period. Later Sewell, Tyler, Young and Conand (1997) showed that gonad development varies in holothurians as a function of taxonomic position, geographical location and habitat, even within individuals in the same location. The aim of this paper is to present the main features of the reproductive biology of $H$. forskali in a bed of the Ría de Vigo, based on histological examination of the gonads and gonad indices, as well as to investigate the relationship of the reproductive cycle with the main environmental variables. This knowledge would allow the development of effective fishery management strategies, taking steps toward conservation.

\section{MATERIALS AND METHODS}

Sampling collection: Samples were taken fortnightly (each comprising 30 individuals) during 2018 from the Ría de Vigo (Galicia, NW Spain) (42॰14'65" N \& 8 49'63.4" W) (Fig. 1), by scuba-diving, at a depth of $10 \mathrm{~m}$, with a total of 630 individuals. Samples were put in plastic recipients with seawater and were brought to 


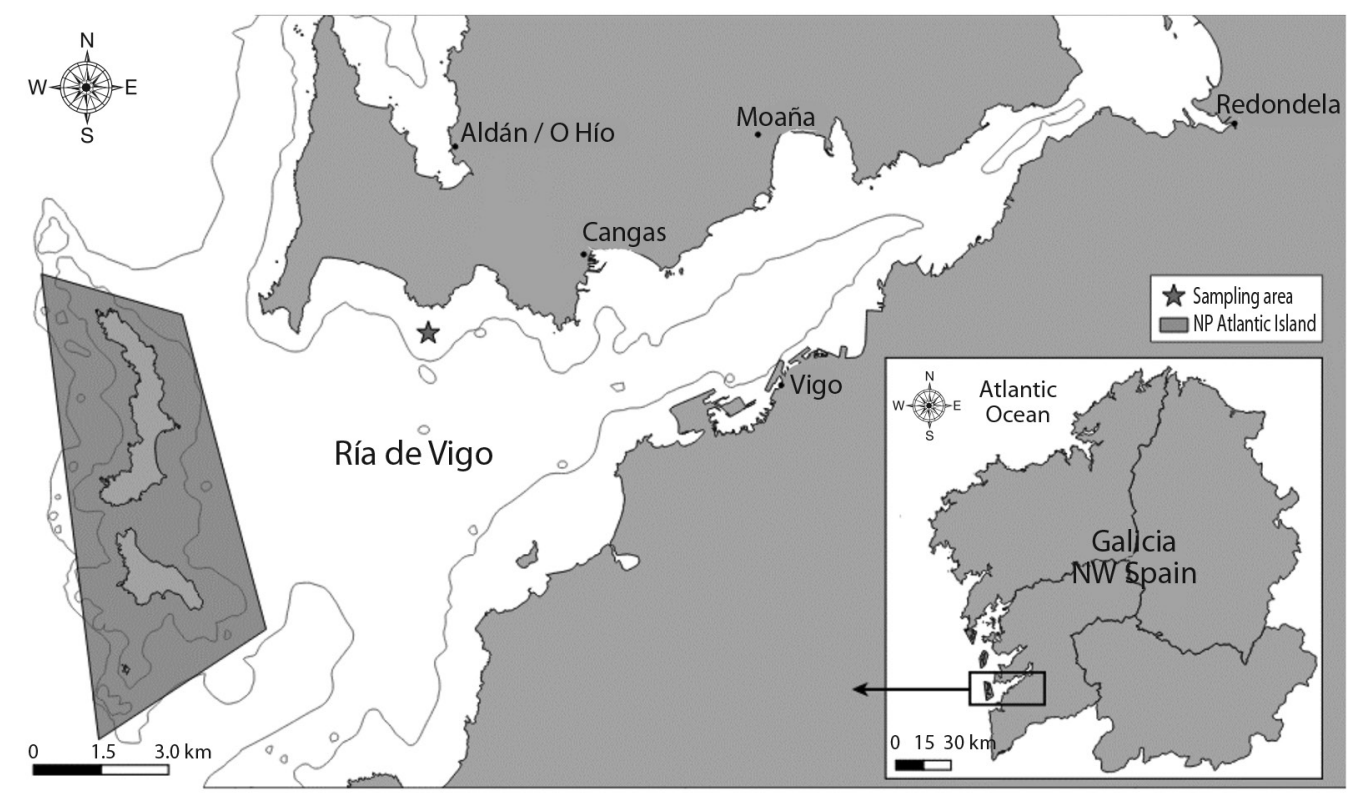

Fig. 1. Location of the sea cucumber studied population (star).

laboratories at Estación de Ciencias Mariñas de Toralla (ECIMAT, University of Vigo).

Histological analyses and gonadal condition index (GCI): Individuals were relaxed for 15 min with $5 \% \mathrm{MgCl}_{2}$ before the following measurements were taken: total length (Lt) and total wet weight $(\mathrm{Wt})$. For histological analysis, a piece of gonad was dissected and routinely processed for histology: i.e. fixed in Davidson formaldehyde for $24 \mathrm{~h}$, dehydrated in an ethanol series, embedded in paraffin, sectioned at $5 \mu \mathrm{m}$ and stained with hematoxylin and eosin (Howard \& Smith, 1983).

A gonadal status was assigned to each individual according to a scale modified from Tuwo et al. (1992), Ramofafia, Battaglene, Bell and Byrne (2000), Navarro et al. (2012) and Santos et al. (2016), which describes a new stage of gonadal restoration, not described until now for this species far as authors know. Gonad development was therefore scored in five stages: 0 (sexual rest), 1 (start of gametogenesis), 2 (advanced gametogenesis), 3 (maturation), 4A (spawning), 4B (gonad restoration) and 5 (exhaustion). For all collected individuals, the gonad was removed, weighed (Gw) and measured (Gl). The eviscerated body weight (Ew), which corresponded to the body wall weight, excluding internal organs was also recorded. The eviscerated body and the gonad were dried for $48 \mathrm{~h}$ at $80{ }^{\circ} \mathrm{C}$ to obtain dry weight of the gonad (Gd) and dry weight of the eviscerated body $(\mathrm{Ed})$.

Two gonadal condition indices (GCI) were calculated using wet and dry weights of the body wall and gonads (Tuwo et al., 1992; Navarro et al., 2012): GCI $_{1}=$ Gd100/Ed and $\mathrm{GCI}_{2}=\mathrm{Gw} 100 / \mathrm{Ew}$.

The GCI values were plotted using the mean and the standard deviation as estimators of the central trend of the sample. Progress through the gametogenic stages was determined by the histological analyses and changes in the GCI; it was compared to confirm the correlation between both methods.

Environmental variables: The environmental variables selected to study its effect on the reproductive cycle of $H$. forskali were sea water temperature and photoperiod. Water temperatures were obtained from Torallamar 
(Oceanographic and Meteorological Information Portal developed by the Physical Oceanography Group and the staff of the Marine Research Center of the University of Vigo) (https://www. pangaea.de/?q=event $\% 3$ Alabel\%3ACIM-ECIMAT) (González, Herrera \& Varela, 2020) and the number of hours of light per day was provided by the reference meteorological station (www.meteogalicia.es).

Chi-square analysis was performed on the data of all samples analyzed by histological methods to test possible deviations from the 1:1 ratio of the male:female ratio. The normality of the size and weight distribution was evaluated by the Shapiro-Wilk test. The relationship between size/weight and sex was examined by a non-parametric test, unpaired two-samples Wilcoxon test. The homogeneity of variance (Levene test) and normality (Shapiro test) in the GCI between groups was not achieved. Therefore, to study possible differences of the GCI between variables (sex-month and sexseason) it has been used a robust method of a single factor Welch-ANOVA for each of the settings and Games-Howell post-hoc test to stablish pairwise comparisons of means. Two-way
ANOVA to explore single and combined effects of sex, months and seasons over GI (Wilcox, 2012; Liu, 2015; Mair \& Wilcox, 2020).

\section{RESULTS}

Population characteristics: Of the 630 individuals, $49.37 \%$ were males, $45.24 \%$ females and $5.40 \%$ were undetermined sex (Fig. 2). The sex ratio for all sampled specimens not differ significantly from 1:1 $\left(\chi^{2}=\right.$ $1.1342 \mathrm{P}>0.05)$. All indeterminate individuals correspond to the period of sexual rest, when the sexes cannot be differentiated. The average weight $( \pm$ SD) of the males was 262.47 $\pm 83.47 \mathrm{~g}$ and of females $271.62 \pm 83.46$ g; average length $( \pm \mathrm{SD})$ was $27.68 \pm 5.04$ and $27.60 \pm 5.04 \mathrm{~cm}$, respectively (Table 1). Although females were bigger (in weight) than males, no significant differences in weight were found between the sexes (Wilcoxon, $\mathrm{P}$ $>0.05)$. Significant differences were found between gonad measurements and sex. Males had longer gonads than females, but weighed less (Wilcoxon, $\mathrm{P}<0.05$ ).

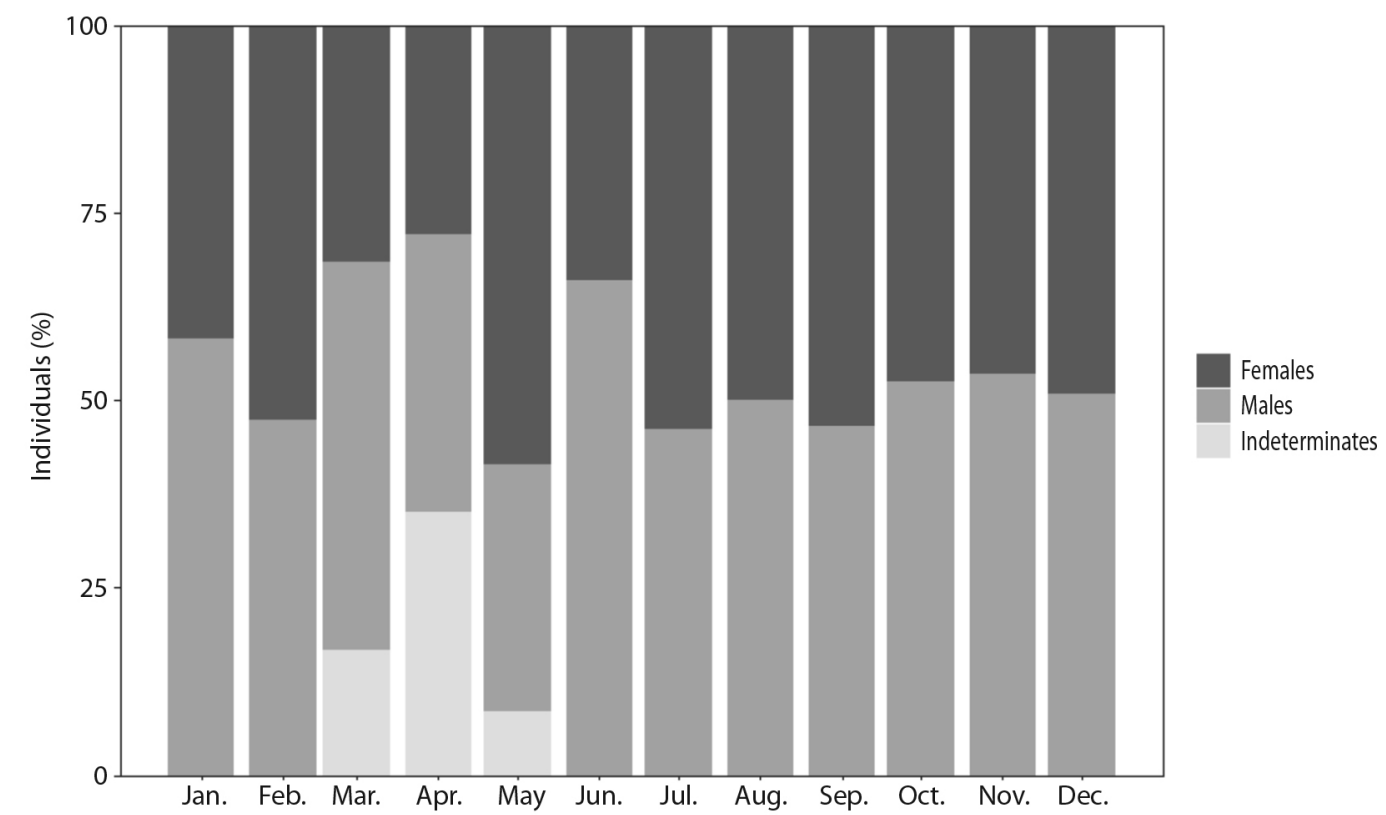

Fig. 2. Proportion of sex of $H$. forskali by monthly sample $(\mathrm{N}=630)$. 
TABLE 1

Biometric data attending to sex

\begin{tabular}{lccccccc} 
& & \multicolumn{3}{c}{ Wet weight $(\mathrm{g})$} & \multicolumn{3}{c}{ Length $(\mathrm{cm})$} \\
& $\mathrm{N}^{*}$ & Mean $\pm \mathrm{SD}$ & Min & Max & Mean \pm SD & Min & Max \\
Males & 311 & $262.47 \pm 83.47$ & 100.4 & 522 & $27.68 \pm 5.04$ & 15 & 45 \\
Females & 285 & $271.62 \pm 83.46$ & 109.35 & 622 & $27.60 \pm 5.04$ & 12 & 42 \\
Undetermined & 34 & $241.94 \pm 70.07$ & 122 & 451 & $27.06 \pm 4.13$ & 19.5 & 37 \\
\hline
\end{tabular}

$* \mathrm{~N}=$ Population size, Mean \pm standard deviation, Min $=$ minimum size, Max $=$ maximum size

Histological analyses: seven stages were defined for $H$. forskali based on histological observations (Table 2). A gonadal status was assigned to each individual according to following scale:

Stage 0 - Sexual rest: most of the gonad is occupied by connective tissue. The tubules are small with very thick walls. There may be primary germ cells but it is not possible to differentiate the sex (Fig. 3A). This stage remains from March to May, predominating in April.

Stage 1- Start of gametogenesis: the wall of the tubule is reduced, but the connective tissue still abounds. In males the germinal epithelium forms numerous folds extending to the lumen. The tubules are full immature cells: oogonias and previtelogenic oocytes adhered to the walls of the tubule in females (Fig. 3B) and spermatogonia of spherical appearance and primary spermatocytes in males (Fig. $3 \mathrm{C})$. This stage predominates from the end of April to July.

Stage 2 - Advanced gametogenesis: the inside of the tubule is filling up of cells, the wall goes away slimming down and the folds begin to disappear as gametogenesis progresses. All maturity stages of the reproductive cells are observed, with more germ cells than mature ones (in number). The immature oocytes are fully adhered to the wall of the follicle while mature oocytes are attached by one peduncle or free in the follicle (Fig. 3D). The immature sperm (spermatogonia, spermatocytes, and spermatids) are close to the follicle wall and mature sperm (with tail) occupies the center (Fig. 3E). This stage predominates from July to October.
Stage 3 - Maturation: the tubules are very big; have a thin wall, the longitudinal folds in them disappear and no germ cells are found. In females, oocytes measure $162.68 \pm 6.1$ $\mu \mathrm{m}$ and may acquire polygonal forms due to them under pressure (Fig. 3F). In males, sperm occupy all the lumen, hold on strongly and the longitudinal folds disappear (Fig. 3G). This stage is more frequent between September and February.

Stage 4A - Spawning: the tubule wall remains thin, with strangulations, and as the stage progresses this begins to thicken again. As a result of the partial release of gametes, follicular pressure decreases, empty spaces are observed inside the follicles (Fig. $3 \mathrm{H}$ for females and Fig. 3I for males). Disorganization of the sperm is stands out in males. This stage predominates from the end of October to March.

Stage 4B - Gonad restoration: after the spawn, a new line of germ cells appears on the wall of the tubules. This stage is similar to stage 2, but it differs in the big size of tubules, in the absence of connective tissue and in that the wall is thin (Fig. 3J for females and Fig. $3 \mathrm{~K}$ for males). In males there is a separation between the mature spermatocytes at the center of the lumen and the immature spermatocytes at the periphery of the follicles. This stage is more frequent between December and April but in a low number of individuals.

Stage 5 - Exhaustion: the tubules with numerous folds begin to degenerate (phagocytic cells appear), so they decrease in number and size, being replaced by connective tissue. In females, residual oocytes can be observed 
TABLE 2

Description of each gonadal state for females and males

\begin{tabular}{|c|c|c|c|}
\hline Stage & Month & Males & Females \\
\hline 0 : sexual rest & March-May & $\begin{array}{l}\text { Abundance of connective tissue } \\
\text { Small tubules }\end{array}$ & $\begin{array}{l}\text { Abundance of connective tissue } \\
\text { Small tubules }\end{array}$ \\
\hline $\begin{array}{l}\text { 1: start of } \\
\text { gametogenesis }\end{array}$ & April- July & $\begin{array}{l}\text { Abundance of connective tissue } \\
\text { Small tubules } \\
\text { Germinal epithelium with numerous folds } \\
\text { Immature cells: spermatogonia and } \\
\text { primary spermatocytes }\end{array}$ & $\begin{array}{l}\text { Abundance of connective tissue } \\
\text { Small tubules } \\
\text { Immature cells: oogonias and } \\
\text { previtellogenic oocytes adhered to the } \\
\text { walls }\end{array}$ \\
\hline $\begin{array}{l}\text { 2: advanced } \\
\text { gametogenesis }\end{array}$ & July-October & $\begin{array}{l}\text { Inside of the tubule is filling up of cell } \\
\text { Wall goes away slimming down } \\
\text { Folds begin to disappear } \\
\text { Cells in all stages of development } \\
\text { Spermatogonia, spermatocytes, and } \\
\text { spermatids are close to the follicle wall } \\
\text { and mature sperm (with tail) occupy the } \\
\text { center }\end{array}$ & $\begin{array}{l}\text { Inside of the tubule is filling up of cell } \\
\text { Wall goes away slimming down } \\
\text { Cells in all stages of development } \\
\text { Immature oocytes adhered to the wall } \\
\text { and mature oocytes attached by one } \\
\text { peduncle or free in the follicle }\end{array}$ \\
\hline 3: maturation & $\begin{array}{l}\text { September- } \\
\text { February }\end{array}$ & $\begin{array}{l}\text { Big tubules } \\
\text { Thin wall } \\
\text { No folds } \\
\text { No germ cells } \\
\text { Sperm occupy all the lumen } \\
\text { Filled tubules }\end{array}$ & $\begin{array}{l}\text { Big tubules } \\
\text { Thin wall } \\
\text { No germ cells } \\
\text { Polygonal oocytes } \\
\text { Filled tubules }\end{array}$ \\
\hline 4A: spawning & October- March & $\begin{array}{l}\text { Big tubules } \\
\text { Thin wall with strangulations } \\
\text { No folds } \\
\text { No germ cells } \\
\text { Empty spaces } \\
\text { Disorganization of the sperm }\end{array}$ & $\begin{array}{l}\text { Big tubules } \\
\text { Thin wall with strangulations } \\
\text { No germ cells } \\
\text { Follicular pressure decreases } \\
\text { Empty spaces }\end{array}$ \\
\hline $\begin{array}{l}4 \mathrm{~B}: \text { gonad } \\
\text { restoration }\end{array}$ & December- April & $\begin{array}{l}\text { Big tubules } \\
\text { Thin wall with strangulations } \\
\text { Absence of connective tissue } \\
\text { New line of germ cells on the wall of the } \\
\text { tubules } \\
\text { Mature spermatocytes in the center } \\
\text { Immature spermatocytes in the periphery } \\
\text { of the follicles }\end{array}$ & $\begin{array}{l}\text { Big tubules } \\
\text { Thin wall with strangulations } \\
\text { Absence of connective tissue } \\
\text { New line of germ cells on the wall of } \\
\text { the tubules } \\
\text { Mature oocytes in the center } \\
\text { Previtellogenic oocytes in the periphery } \\
\text { of the follicles }\end{array}$ \\
\hline 5: exhaustion & March- May & $\begin{array}{l}\text { Numerous folds } \\
\text { Phagocytic cells } \\
\text { Small tubules } \\
\text { Connective tissue } \\
\text { Phagocytic activity }\end{array}$ & $\begin{array}{l}\text { Phagocytic cells } \\
\text { Small tubules } \\
\text { Connective tissue } \\
\text { Residual oocytes } \\
\text { Phagocytic activity }\end{array}$ \\
\hline
\end{tabular}

(Fig. 3L) and in males, the spermatozoa are disGonadal condition index (GCI), reproorganized (Fig. 3M). The gonad is practically ductive cycle and environmental factors: reabsorbed by phagocytic activity. This stage predominates from March to May. The mean $( \pm \mathrm{SD})$ obtained from $\mathrm{GCI}_{2}$ was $12 \%( \pm 11 \%)$ while that of $\mathrm{GCI}_{1}$ was $11 \%$ 

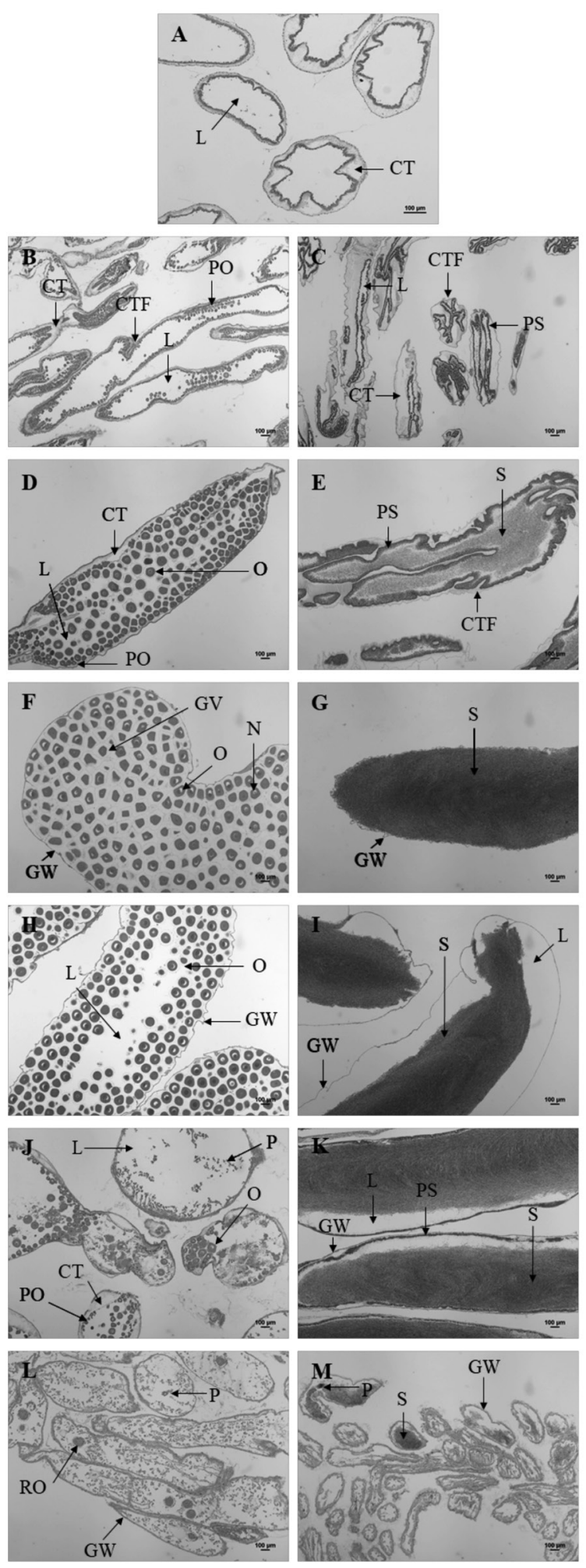

( $\pm 11 \%$ ). Despite the fact that the $\mathrm{GCI}_{2}$ was higher except in the months of sexual rest (March, April and May), the trend throughout the year is similar in both indices (Fig. 4A, 4B and 4C). Consequently, only $\mathrm{GCI}_{1}$ will be kept in mind for using the dry weight and not the wet weight, resulting in less error. The GCI varies throughout the year, significant differences were found between months (Welch's ANOVA, $\mathrm{F}_{11,216.33}=146.26, \mathrm{P}$ $<0.05$ ) and seasons (Welch's ANOVA, $\left.\mathrm{F}_{3,360.46}=267.16, \mathrm{P}<0.05\right)$. Considering two-to-two comparisons between months, there would be no difference between the winter months and the spring months. June shows more similarity with the spring months, August with the winter ones and in the winter months, September differs from November.

There were significant differences between sexes on the yearly mean $\mathrm{GCI}_{1}$ (Welch's ANOVA, $\mathrm{F}_{1,524.03}=6.05, \mathrm{P}<$ $0.05)$ obtaining an annual mean $( \pm \mathrm{SD})$ $12.2 \%( \pm 11.7 \%)$ for females and 10.2 $\%( \pm 8.8 \%)$ for males. There is interaction of the $\mathrm{GCI}_{1}$ between sex-season (sex $\mathrm{x}$ season, two-way ANOVA, $\mathrm{P}<0.05$ ) and sex-month (sex $x$ month, two-way ANOVA, $\mathrm{P}<0.05$ ), the difference in the $\mathrm{GIC}_{1}$ between sexes is not constant throughout the year, that difference is more important in winter and more constant in the other seasons (Fig. 4D). The maximum values of the gonad index

Fig. 3. Gametogenic stages of female (B, D, F, H, $\mathbf{J}, \mathbf{L})$ and males $(\mathbf{C}, \mathbf{E}, \mathbf{G}, \mathbf{I}, \mathbf{K}, \mathbf{M})$ Holothuria forskali. A. Stage 0-sexual rest in indeterminates. B-C. Stage 1-start of gametogenesis. D-E. Stage 2-advanced gametogenesis. F-G. Stage 3-maturation. H-I. Stage 4A-spawning. J-K. Stage 4B-gonad restoration. M-N. Stage 5-exhaustion. CT: connective tissue, CTF: connective tissue folds, GV: germinal vesicle, $\mathrm{GW}$ : gonadal wall, $\mathrm{L}$ : lumen, N: nucleus, O: oocyte, P: phagocytes, PO: previtellogenic oocytes, PS: primary spermatocytes, RO: residual oocyte, S: spermatozoa (bar: $100 \mu \mathrm{m}$ ). 

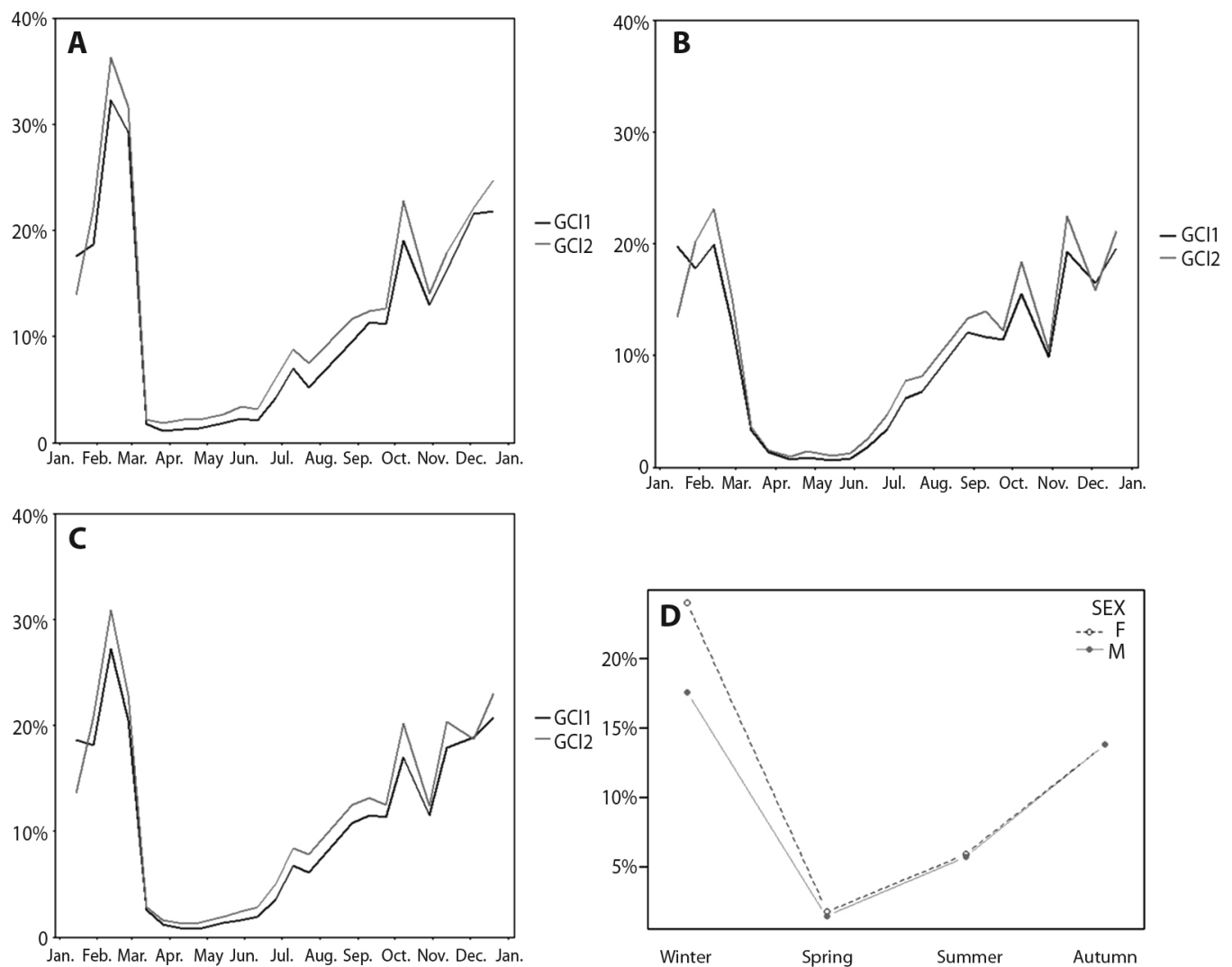

Fig. 4. H. forskali gonad condition index (GCI) through the year 2018. A. Represent GCI1 vs. GCI2 in females. B. Represent

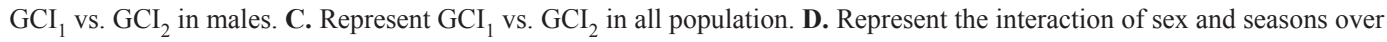
GCI. GCI ${ }_{1}$-dark grey line, $\mathrm{GCI}_{2}$-light grey line, females-empty circles and males-full circles.

were achieved in February during the winter season, whereas in spring the lowest values were found, corresponding to the sexual rest stage (stage 0 ) when there is hardly any gonad. The successive ups and downs from October to January may be indicative of partial spawning, and those in February, of the main spawning.

The study of the reproductive cycle (Fig. 5) began in winter, when the H. forskali species was in the maturation (stage 3) and spawning (stage 4A) stages, with the predominance of the latest ones. Then, the gonadal remnants were resorbed to a stage of sexual exhaustion (stage 5) and rest (stage 0 ) that occurs in spring, finding a higher percentage of individuals in these stages in April. After a period of sexual rest (the total number of individuals sampled in this stage is never observed), a new gonadal cycle begins. Individuals in the beginning phase of gametogenesis (stage 1) were observed from April to summer, a period in which this stage dominates together with that one of advanced gametogenesis (stage 2). At the end of June, the first mature individuals appeared, the stage of maturation remained until the end of the year and overlaps with the first spawning which started in November. The stage of gonad restoration (4B) was observed after the first spawning, in the month of December and continued always in a low percentage of the population until the rest stage (end of April). Something to note, is that the stage of gonadal recovery was 


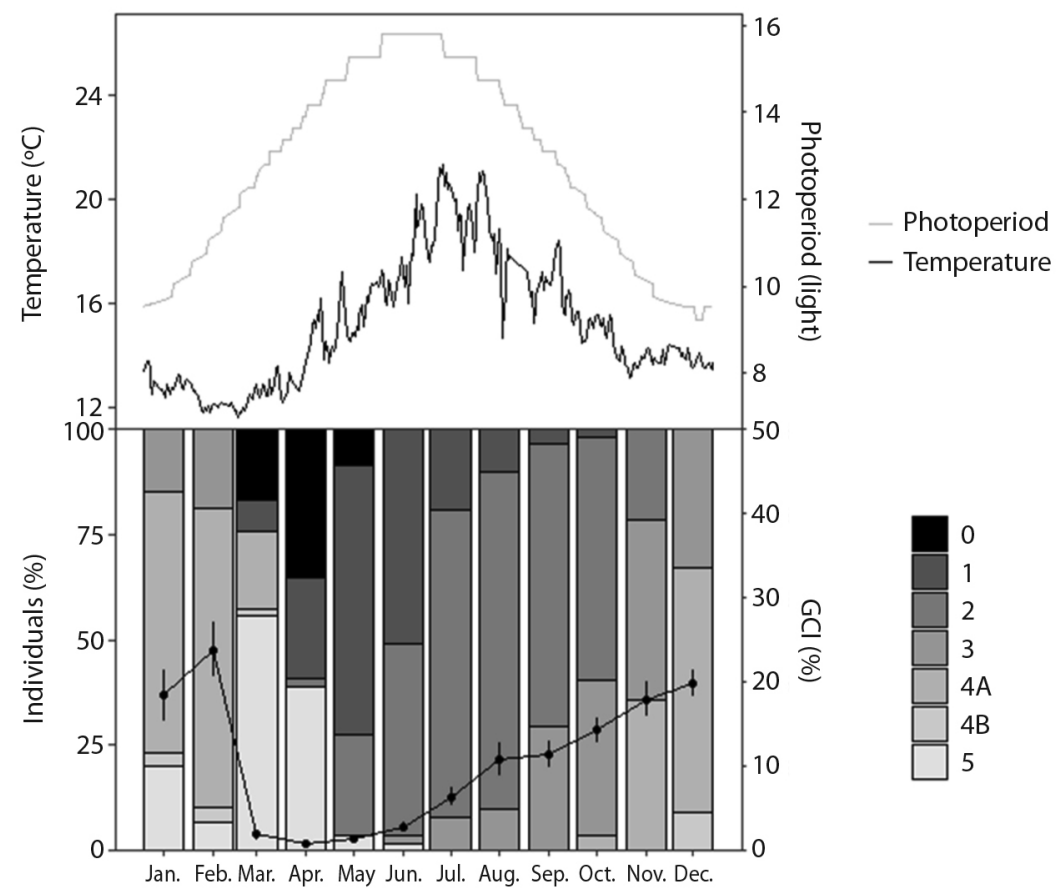

Fig. 5. Temporal distribution of gametogenic stages of $H$. forskali and variation in gonadal condition index (GCI; mean). 0: sexual rest; 1: start of gametogenesis; 2: advanced gametogenesis; 3: maturity; 4A: spawning; 4B: gonad restoration and 5: exhaustion. Also are represented monthly variations in water temperature and in the hour of light.

uncommon (Fig. 6), and it appeared in females during the months of March (Fig. 6A) and April. However, it appeared in males between December and February (Fig. 6B).

The studied population showed some asynchronous gametogenic development between sexes (Fig. 6), females initiated maturing earlier than males. It is worth noting that, in addition, the females remained in a longer stage of maturation, finding mature females in a higher percentage until March. Another observation to highlight between the sexes was that in males the first gonadal restoration was observed in December and continued until the exhaustion stage, whereas in the females it appeared coinciding with the resting stage (March).

When representing the reproductive cycle against environmental variables (Fig. 5), it can be observed that there is a negative correlation between gonadal development and photoperiod, as the hours of light increase, the gonadal condition index decreases, coinciding with the stages of sexual exhaustion and rest. The sexual rest coincides with the increase in temperature and hours of light, and the beginning of maturation, with the decrease.

\section{DISCUSSION}

Although some aspects of reproductive biology of $H$. forskali have been studied in other areas, there may be differences from one population to another. Therefore, it was necessary to study the population of the Ría de Vigo in order to carry out proper fisheries management. The first study that reported data on the reproductive cycle of this species was that of Tuwo et al. (1992) in France. As in the French Brittany population, this population did not show significant differences in size between males and females as in many other species (Despalatović, Grubelić, Simunović, Antolić \& Zuljević, 2004; Fajardo-León, Suárez-Higuera, del Valle-Manríquez \& Hernández-López, 

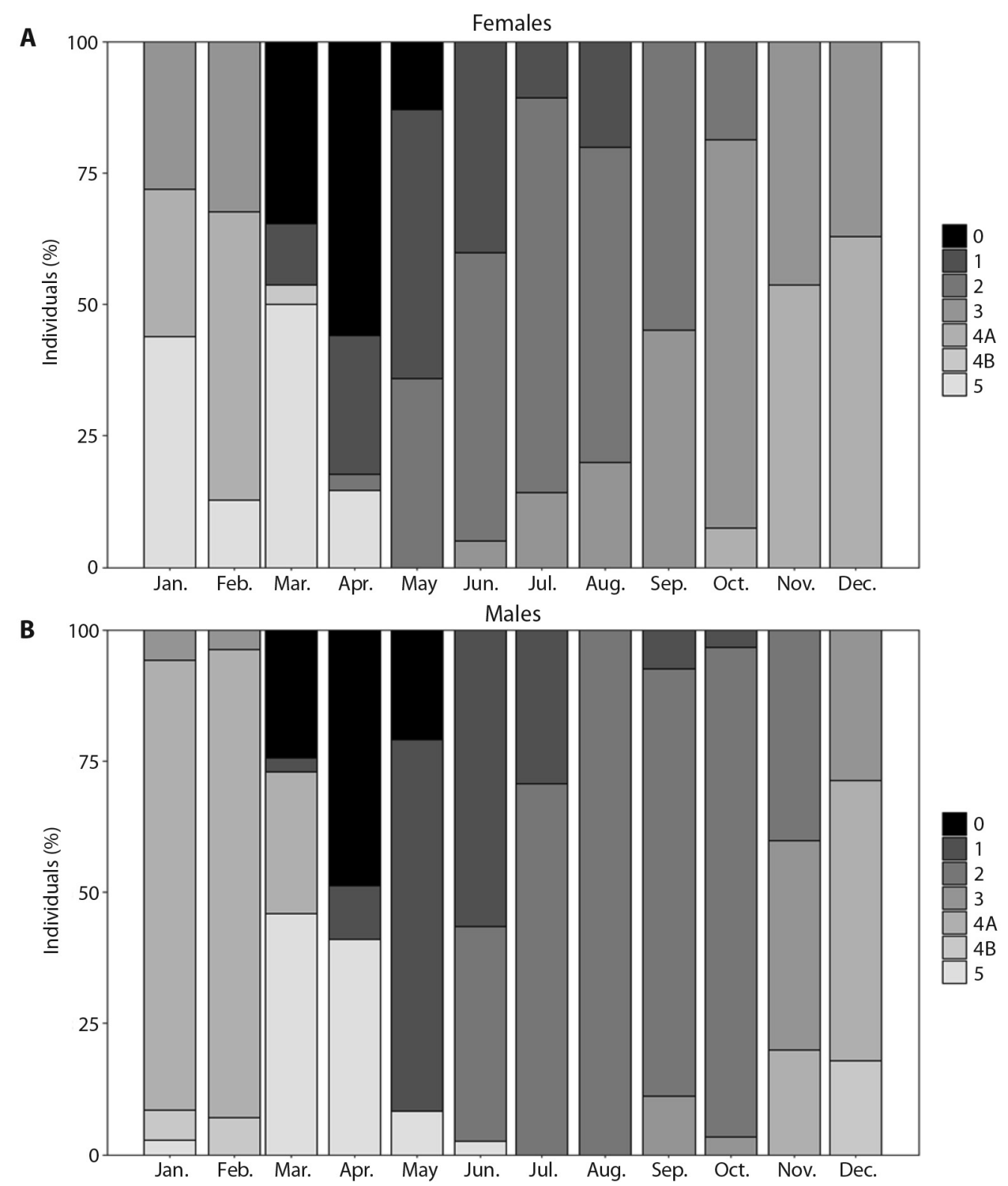

Fig. 6. Temporal distribution of gametogenic stages of $H$. forskali. 0: sexual rest; 1: start of gametogenesis; 2: advanced gametogenesis; 3: maturity; 4A: spawning; 4B: gonad restoration and 5: exhaustion. A. Females. B. Males.

2008), and the sex ratio did not differ from the $1: 1$. In contrast, the population of the Ría de Vigo presents bigger individuals with an average weight of $265.42 \pm 83.40 \mathrm{~g}$ compared to $152.5 \mathrm{~g}$ of the French population. This may be due to the fact that the holothurian fishery in
Galicia is still very recent or that Galicia waters are richer in nutrients.

Despite the fact that the sex ratio is $1: 1$ in most holothurians (Ramofafia, Byrne \& Battangle, 2001; Asha \& Muthiga, 2008; Fajardo-León et al., 2008; Kazanidis et al., 
2010; Peters-Didier, Pardo, Garrido \& Gallardo, 2018; Cahuzac et al., 2019), as in the Ría de Vigo, some species demonstrated an unbalanced ratio (Costelloe, 1985; Navarro et al., 2012; Omar, Abdel Razek, Abdel Rahman \& El Shimy, 2013; Pañola-Madrigal, Calderón-Aguilera, Aguilar-Cruz, Reyes-Bonilla \& Herrero-Pérezrul, 2017). In fact, Santos et al. (2016) found in H. forskali, more female than males; these authors explain that the place of sampling is subject to strong tides which is considered to be another major factor affecting the balanced sex ratio due to the fact that strong sea waves often promote species' evisceration as a stress response. However, this result may also be a consequence of the low sample number $(\mathrm{N}=91)$, Tuwo et al. (1992) sampled a total of 409 mature individuals, and in this study, 596 individuals. Shiell \& Uthicke (2006) also found that in Holothuria whitmaei the males and females' ratio did not differ from unity in a population of Western Australia $(\mathrm{N}=325)$, but in a population of Pacific Australia more males than females predominated significantly $(\mathrm{N}=206)$. Something similar happened also happens with the species Isostichopus fuscus in two populations of Mexico (Pañola-Madrigal et al., 2017). Another species of the same genus (Holothuria tubulosa) was studied in the Aegean Sea $(\mathrm{N}=166)$ by Kazanidis et al. (2010) and in the Adriatric sea $(\mathrm{N}=130)$ by Despalatović et al. (2004), both obtained the same result $(1: 1)$ regarding the sex ratio.

The measurements taken from the gonads differ between sexes, agreeing with the data selected by Santos et al. (2016) and Tuwo et al. (1992) to $H$. forskali, male gonads are longer than female gonads but with less weight. This is common in sea cucumbers, females with shorter tubules have a greater quantity because they invest more in reproduction (Shiell \& Uthicke, 2006). The size of the gonad with respect to each sex can differ between species of holothurian and may reflect differences in spawning behavior (Morgan, 2000).

In all the papers reviewed, although they can designate the stages with another name or include 2 stages in 1, basically all of them state a phase of rest, growth, maturation, spawn and exhaustion. However, in this study a gonadal restoration phase has been observed, without going through a previous rest, probably thanks to the high sampling periodicity and by the sample number $(\mathrm{N}=630)$. To understand this stage of gonadal restoration, it is necessary to keep in mind that unlike other species (Costelloe, 1985), H. forskali does not present germ cells in the mature stage. They appear after the first spawning. The gonadal restoration phase is frequent in many bivalves (Suárez, Álvarez, Molist \& San Juan, 2005; Martínez-Castro \& Vázquez, 2012; Hernández-Otero, MartínezCastro, Vázquez \& Macho, 2014) but not in holothurians. The low percentage of individuals found in this stage suggests that those who have gutted use this strategy (gonadal restoration), individuals who have gutted part of the gonad in the period of maturity could regenerate it without going through a period of rest. These individuals begin a new gametogenic cycle without going through a resting stage to save time and not lose the reproductive period. Also, if we keep in mind the GCI, before appreciating the steepest peak (February) we can observe other weaker prior peaks, and as Tuwo et al. (1992) indicate, after spawning, almost the entire content of the gonads is released, causing the decrease in GCI. If this is compared with what happens in two species of mollusks (Darriba, San Juan \& Guerra, 2005), one of them with recovery status and the other without it, the following can be observed: Ensis siliqua is a species that does not exhibit gonadal restoration during the spawning period and for this reason there is only one maximum in the GCI rather than consecutive maxima, which would be indicative of consecutive spawns over the course of several months, as it occurs in Ensis arcuatus. Females start before maturation, which may be because it was underestimating the rate of mature males, since this status has only been assigned to males in which the tubule walls were free of immature cells. Although the criteria were the same in both sexes, males may release sperm before immature cells stop proliferating. In addition, some females start 
a new cycle of gametogenesis without going through a resting stage, which may be the reason why some mature females appear in the month of July.

The reproductive cycle of $H$. forskali was determined based on the histological analysis and the GCI. The influence of environmental variables on it was also observed. Different gonadal indices have been used (Pérez \& Marcos, 1985) from the beginning, with them a first idea of the periodicity of the reproductive cycles can be obtained (Engstrom, 1980). Two indices were used in this study, the $\mathrm{GCI}_{1}$ considering the dry weight and the $\mathrm{GCI}_{2}$ with the wet weight, this is the reason why the $\mathrm{GCI}_{2}$ is superior and why the differences between indices decrease in the months of rest when the gonad is reduced, thus accumulating less water inside. The highest percentages of $\mathrm{GCI}_{1}$ are reached between October and February. The gonadal cycle of $H$. forskali in Galicia shifts one month when compared to the study carried out in Brittany (France) (Tuwo et al., 1992), in which they obtained the highest percentages of $\mathrm{GCI}_{1}$ between November and March, on the other side it agrees with the data obtained by Santos et al. (2006) in Peniche (Portugal), who found the highest values in November and February.

The $\mathrm{GCI}_{1}$ trend of the was similar in both sexes, but females have a higher ICG than males, this difference being more evident in the reproductive period just like in other species (Sewell \& Bergquist, 1990; Asha \& Muthiga, 2008; Omar et al., 2013; Woong, Lee, Yoo \& Hang, 2017). These results coincide with those obtained by Tuwo et al. (1992) in this species, but they differ from those found by Santos et al. (2006), also for $H$. forskali. No significant differences were found either between sexes or among months and in other species the opposite occurs, where the male has a higher GCI than that of the females except in the maturation stage (Peters-Didier et al., 2018). Other species of the same genus, such as Holothuria sanctori, have the highest GCI values in the summer months and the lowest between November and March. Its reproductive cycle is contrary to that of $H$. forskali, because despite being an Atlantic species in this region there is a subtropical climate (Navarro et al., 2012).

Comparison of the histological results with GCI indices suggests that GCI is a good indicator for the gonadal stage. A good homology between the GCI and the stages of the gonads with a histological analysis has been reported for various aspidochirote holothurians (Conand, 1993; Shiell \& Uthicke, 2006; Kazanidis et al., 2010), thus GCI seems to be reliable for the description of the reproductive cycle in holothurians. Although a first idea of the periodicity of the reproductive cycles can be obtained through GCI (Engstrom, 1980) such as Fajardo-León et al. (2008) indicate in their studies, the GCI can vary with the physiological stage of the organism, due to environmental factors and diet, therefore it is necessary to complement it with a histological study.

$H$. forskali showed an annual cycle, with spawning in winter and rest in spring. These results concur with that found for this species by Tuwo et al. (1992), the maturation starts in October. However, these authors conclude that there is a short spawning in April, but in this case, we have found partial spawns from November and a large one in February. On the other hand, Santos et al. (2006) did not find a resting period in males and they found resting females in January, May and June. These differences can be attributed to the fact that the frequency of gonad maturity stages used by these authors was determined by the physical characteristics of large tubules and not by histology. In $H$. forskali there could be a latitudinal gradient as with other species. It has been noticed that the sexual rest of this species in Galicia-Spain takes place one month earlier than in Brittany-France (Tuwo et al., 1992) and some females were found at rest in January in Peniche-Portugal (Santos et al., 2016), two months earlier than in Spain. A gradient latitudinal from south to north has been described (Fajardo-León et al., 2008) to Parastichopus parvimensis, in the south the maturity-spawning period is in winter / spring and in the north in spring / summer. 
Correlation of reproductive cycle with conditions existing in the natural environment has been examined for a number of sea cucumbers (Costelloe, 1985; Sewell \& Bergquist, 1990; Hamel, Himmelman \& Dufresne, 1993; Hopper, Hunter \& Richmond, 1998; Asha \& Muthiga, 2008; Pañola-Madrigal et al., 2017) since, the reproductive activities of echinoderms are regulated by endogenous factors, which, in turn, are affected by exogenous environmental factors (Costelloe, 1985). According to Costelloe (1985), the environmental stimuli that have the most influence on sexual cycles directly or indirectly are: changing temperature, salinity, photoperiod, food and habitat availability and juvenile recruitment and survival. In this study, two of these factors have been studied; temperature and photoperiod.

The reproduction pattern of this species is contrary to that the other holothurians, which reproduce during the warmer months when the days are longer. In this way the larvae have greater food availability due to the proliferation of phytoplankton (Cameron \& Fankboner, 1986; Sewell \& Bergquist, 1990; Conand, 1993; Hamel et al., 1993; Morgan, 2000; Ramofafia et al., 2001; Guzmán et al., 2003; Despalatović et al., 2004; Kazanidis et al., 2010; Omar et al., 2013; Pañola-Madrigal et al., 2017). The spawning period of $H$. forskali takes place when the temperatures are lower as well as are the species Holothuria whitmaei (Shiell \& Uthicke, 2006), Aslia lefevrei (Costelloe, 1985) or Holothuria nobilis (Conand, 1993). In fact, the induction of spawning by thermal stimulus supports the suggestion that temperature may be a factor that cues gamete release. This is a widely used spawning method in the cultivation of holothurians (Rakaj et al., 2018; Hartai \& Pringgenies, 1998; Agudo, 2006) and has also been successful for this species (Laguerre et al., 2020).

It can be observed that there is a negative correlation between gonadal development and photoperiod, as the hours of light increase, the gonadal condition index decreases. By contrast, according to Cameron \& Fankboner (1986), most holothurians according spawn in longer photoperiod; for example, Parastichopus californicus initiates spawning with the increase in daylight length and intensity which means an increase in phytoplankton biomass. The same happens with Actinopyga mauritiana, the observations of Hopper et al. (1998) and Ramofafia et al. (2001) support the suggestion that spawning coincided with increased water temperature and day length, and the beginning of the wet season.

The strategy followed by $H$. forskali could be to accumulate reserves in the hot months with more hours of light, when the food is predominant, in order to use these reserves during the maturation and spawning periods together with the accessible food in this moment. In this way, the larvae would be favored, they would have greater availability of food, since from February the hours of light and the temperature increase. This idea was also proposed by Costelloe (1985) and Costelloe \& Keegan (1984) for A. lefevrei, this species accumulates most of the nutrients during the warmer months and depends on these food reserves for general metabolism and gametogenic activity during the winter. Galicia has waters very rich in nutrients and although the upwelling events are a frequent phenomenon during the spring and summer months, there is also in the possibility of observing some these events during the maturation-spawning periods of this species (November-February) (Álvarez, Prego, deCastro \& Varela, 2012). The results of this study confirm that the abiotic factors are probably important signals for the gonadal development of this species.

Data obtained on the reproductive biology of $H$. forskali can be useful to implement a sustainable exploitation of this resource, as it would help to stablish a harvest season and a closure during the spawning period. The sea cucumber fishery is recent in Galicia and therefore, it is important to develop this type of study and apply effective management measures that avoid overexploitation of this sea cucumber species.

The tendency of the two GCI was the same, the $\mathrm{GCI}_{2}$ is a good tool to be used by 
fishermen's guilds to check the maturity period in which the population is, because it is faster and does not require special equipment.

The closure period must be adapted to the reproductive stage. Thus, it is recommended to avoid harvesting between November and February in order to increase the spawning potential ratio and consequently the recruitment.

Ethical statement: authors declare that they all agree with this publication and made significant contributions; that there is no conflict of interest of any kind; and that we followed all pertinent ethical and legal procedures and requirements. All financial sources are fully and clearly stated in the acknowledgements section. A signed document has been filed in the journal archives.

\section{ACKNOWLEDGMENTS}

To all the personnel of the Toralla Marine Science Station (ECIMAT) and to the fisher's guild of Cangas. This study was conducted under the project "Study of the biology, population status and genetic diversity of holoturia (Holothuria forskali) in the Ría de Vigo", financially supported by the Consellería do Mar, Xunta de Galicia.

\section{RESUMEN}

Ciclo reproductivo del pepino de mar Holothuria forskali (Holothuriida: Holothuriidae) en la Ría de Vigo (NW de España)

Introducción: La explotación del pepino de mar (Holothuria (Panningothuria) forskali) en la Ría de Vigo (NO España) es reciente (2015) y se ha llevado a cabo con poca o ninguna información sobre algunos aspectos biológicos claves como la reproducción, el reclutamiento o el crecimiento. Objetivo: Describir el ciclo reproductivo de H. forskali en un banco de la Ría de Vigo. Métodos: Se tomaron muestras quincenales durante el 2018. Se calcularon índices de condición gonadal (ICG) y se obtuvieron los estados gonadales siguiendo métodos histológicos clásicos. El estado gonadal de cada individuo se asignó de acuerdo con una escala modificada por otros autores, y en ella se describe un nuevo estado de recuperación gonadal, no descrito hasta ahora para esta especie. Resultados: El ciclo reproductivo de $H$. forskali se caracteriza por una etapa de reposo sexual en primavera, un inicio de la gametogénesis durante el verano y un período de puestas sucesivas intercaladas con recuperaciones gonadales durante el otoño e invierno. La proporción de sexos es 1:1 y la población estudiada no está sincronizada, las hembras inician la maduración antes. La comparación de los resultados histológicos con los índices ICG sugiere que este índice es un buen indicador del estado gonadal. El período de veda debe adaptarse a la etapa reproductiva, por lo que recomendamos evitar la extracción del recurso al menos entre noviembre y febrero para asegurar un mayor número de puestas $y$, en consecuencia, el reclutamiento.

Palabras clave: recuperación gonadal; factores abióticos; proporción sexual; índice de condición gonadal; pesquerías.

\section{REFERENCES}

Agudo, N. (2006). Sandfish hatchery techniques. Australian center for International Agricultural Research (ACIAR). Camberra, Australia.

Álvarez, I., Prego, R., deCastro, M. \& Varela, M. (2012). Galicia upwelling revisited: out-of-season events in the rias (1967-2009). Ciencias Marinas, 38 (1B), 143-159.

Asha, P. S. \& Muthiga, P., (2008). Reproductive biology of the commercial sea cucumber Holothuria spinifera (Echinodermata: Holothuroidea) from Tuticorin, Tamil Nadu, India. Aquaculture International, 16 (3), 231-242.

Bakus, J. G. (1973). The biology and ecology of tropical holothurians. In O. A. Jones \& R. Edeans (Eds.), Biology and Geology of Coral Reefs (pp. 326-367). New York, USA: Academic Press.

Bordbar, S., Anwar, F. \& Saari, N. (2011). High-value components and bioactives from sea cucumbers for functional foods-A review. Marine drugs, 9, 1761-1805.

Cahuzac, S., Conand, C., Govinden, R., Ebrahim, A., Marie, S. \& Léopold, M. (2019). Size at sexual maturity of the flower teatfish Holothuria (Microthele) sp. in the Seychelles. SPC Bêche-de-mer Information Bulletin, 39, 19-26.

Cameron, J. L. \& Fankboner, P. V. (1986). Reproductive biology of the commercial sea cucumber Parastichopus californicus (Stimpson) (Echinodermata: Holothuroidea). I. Reproductive periodicity and spawning behaviour. Canadian Journal of Zoology, 64(1), 168-175.

Chen, J. (2003). Overview of sea cucumber farming and sea ranching practices in China. SPC Bêche de-mer Information Bulletin, 18, 18-23. 
Chen, J. (2004). Present status and prospects of sea cucumber industry in China. In A. Lovatelli, C. Conand, S. Purcell, S. Uthicke, J. F. Hamel \& A. Mercier (Ed.), Advances in Sea Cucumber Aquaculture and Management (pp. 25-38). Rome, Italy: FAO Fisheries and Aquaculture Technical Paper, No. 463.

Conand, C. (1993). Reproductive biology of the holothurians from the major communities of the New Caledonian Lagoon. Marine Biology, 116(3), 439-450.

Conand, C. (2005). Harvest and trade: Utilization of sea cucumbers; sea cucumbers fisheries trade; current international trade, illegal, unreported and un regulated trade, bycatch, socio-economic characteristics of the trade in sea cucumbers. In: Bruckner A (editor) The Proceedings of the Technical workshop on the conservation of sea cucumbers in the families Holothuridae and Stichopodidae. NOAA Technical Memorandum NMFS-OPR 44, Silver Spring, MD 239 pp.

Conand, C. \& Byrne, M. (1993). A review of recent developments in the world sea cucumber fisheries. Marine fisheries Review, 53, 1-13.

Conand, C., Polidoro, B., Mercier, A., Gamboa, R., Hamel, J.F. \& Purcell, S. (2014). The IUCN Red List assessment of aspidochirotid sea cucumbers and its implications. Bêche-de-mer Information Bulletin, 34(5), 3-7.

Costelloe, J. (1985). The annual reproductive cycle of the holothurian Aslia lefevrei (Dendrochirota: Echinodermata). Marine Biology, 88(2), 155-165.

Costelloe, J. \& Keegan, B. F. (1984). Littoral and benthic investigations on the west coast of Ireland. Synonymy, diagnostic morphology, distribution and lifestyle of Aslia lefevrei (Barrois, 1882) (Holothuroidea: Echinodermata). Proceedings of the Royal Irish Academy, 84, 29-34.

Darriba, S., San Juan, F. \& Guerra, A. (2005). Gametogenic cycle of Ensis siliqua (Linnaeus, 1758) in the Ría de Corcubión, northwestern Spain. Journal of Molluscan Studies, 71(1), 47-51.

Despalatović, M., Grubelić, I., Ŝimunović, A., Antolić, B. \& Zuljević, A. (2004). Reproductive biology of the holothurian Holothuria tubulosa (Echinodermata) in the Adriatic Sea. Journal of the Marine Biological Association of the United Kingdom, 84(2), 409-414.

Engstrom, N. A. (1980). Reproductive cycles of Holothuria (Halodeima) floridana, $H$. (H.) mexicana and their hybrids (Echinodermata: Holothuroidea) in southern Florida, U.S.A. International Journal of Invertebrate Reproduction, 2(4), 237-244.

Entrambasaguas, L. (2008). Estudio faunístico y ecológico de los equinodermos del archipiélago de Cabo Verde. (Doctoral dissertation), Universidad de Murcia, Spain.
Fajardo-León, M. C., Suárez-Higuera, M. C. L., del Valle-Manríquez, A. \& Hernández-López, A. (2008). Reproductive biology of the sea cucumber Parastichopus parvimensis (Echinodermata: Holothuroidea) at Isla Natividad and Bahía Tortugas, Baja California Sur, México. Ciencias Marinas, 34(2), 165-177.

González, J., Herrera, J. L. \& Varela, R. A. (2020). CIMECIMAT ocean meteorological station time-seriesphysical oceanography data. PANGAEA, https://doi. org/10.1594/PANGAEA.916030

González-Wangüemert, M., Valente, S., Henriques, F., Domínguez-Godino, J. A. \& Serrão, E. A. (2016). Setting preliminary biometric baselines for new target sea cucumbers species of the NE Atlantic and Mediterranean fisheries. Fisheries Research, 179, 57-66.

González-Wangüemert, M., Domínguez-Godino, J. A. \& Cánovas, F. (2018). The fast development of sea cucumber fisheries in the Mediterranean and $\mathrm{NE}$ Atlantic waters: From a new marine resource to its over-exploitation. Ocean \& Coastal Management, $151,165-177$.

Guzmán, H. M., Guevara, C. A. \& Hernández, I. C. (2003). Reproductive cycle of two commercial species of sea cucumber (Echinodermata: Holothuroidea) from Caribbean Panama. Marine Biology, 142(2), 271-279.

Hamel, J. F, Himmelman, J. H. \& Dufresne, L. (1993). Gametogenesis and spawning of the sea cucumber Psolus fabricii (Duben and Koren). Biology Bulletin, 66(1), 47-57.

Hernández-Otero, A., Martínez-Castro, C., Vázquez, E. \& Macho, G. (2014). Reproductive cycle of Ensis magnus in the Ría de Pontevedra (NW Spain): Spatial variability and fisheries management implications. Journal of Sea Research, 91, 45-57.

Hartai, R. \& Pringgenies, D. (1998). Study to investigate induced spawning methods and larval rearing of the sea cucumber Holothuria scabra. Journal of Coastal Development, 1(3), 219-225.

Hopper, D., Hunter, C. L. \& Richmond, R. H. (1998). Sexual reproduction of the tropical sea cucumber, Actinopyga mauritiana (Echinodermata: Holothuroidea) in Guam. Bulletin of Marine Science, 63(1), 1-9.

Howard, D. W. \& Smith, C. S. (1983). Histological techniques for marine bivalve mollusks. NOAA. Technical Memorandum NMFS-F/NEC, 25,1-97.

IUCN. (2019). The IUCN red list of threatened species (Version 2019-2). Retrieved from https://www.iucnredlist.org/.

Kazanidis, G., Antoniadou, C., Lolas, A., Neofitou, N., Vafidis, D., Chintiroglou, C. \& Neofitou, C. (2010). Population dynamics and reproduction of Holothuria tubulosa (Holothuroidea: Echinodermata) in the 
Aegean Sea. Journal of the Marine Biological Association of the United Kingdom, 90 (5), 895-901.

Laguerre, H., Raymond, G., Plan, P., Améziane, N., Bailly, X. \& Le Chevalier, P. (2020). First description of embryonic and larval development, juvenile growth of the black sea-cucumber Holothuria forskali (Echinodermata: Holothuroidea), a new species for aquaculture in the north-eastern Atlantic. Aquaculture, 521,734961 .

Liu, H. (2015). Comparing Welch's ANOVA, a Kruskal-Wallis test and traditional ANOVA in case of Heterogeneity of Variance (Master thesis). Virginia Commonwealth University, USA.

Mair, P. \& Wilcox, R. (2020). Robust statistical methods in $\mathrm{R}$ using the WRS2 package. Behavior Research Methods, 52, 464-488.

Martínez-Castro, C. \& Vázquez, E. (2012). Reproductive cycle of the cockle Cerastoderma edule (Linnaeus, 1758 ) in the Ria de Vigo (Galicia, Northwest Spain). Journal of Shellfish Research, 31(3), 757-767.

Mehmet, A., Hüseyin, S., Bekir, T., Yilmaz, E. \& Sevim, K. (2011). Proximate composition and fatty acid profile of three different fresh and dried commercial sea cucumbers from Turkey. International Journal of Food Science \& Technology, 46(3), 500-508.

Meteorological station. Retrieved from https://www.meteogalicia.gal/web/inicio.action.

Morgan, A. D. (2000). Aspects of the reproductive cycle of the sea cucumber Holothuria scabra (Echinodermata: Holothuroidea). Bulletin of Marine Science, 66(1), 47-57.

Navarro, P. G, García-Sanz, S. \& Tuya, F. (2012). Reproductive biology of the sea cucumber Holothuria sanctori (Echinodermata: Holothuroidea). Scientia Marina, 76(4), 741-752.

Oceanographic and Meteorological Information Portal developed by the Physical Oceanography Group and the staff of the Marine Research Center of the University of Vigo. Retrieved from https://www.pangaea. de/?q=event $\% 3$ Alabel\%3ACIM-ECIMAT.

Omar, H. A., Abdel Razek, F. A., Abdel Rahman, S. H. \& El Shimy, N. A. (2013). Reproductive periodicity of sea cucumber Bohadschia vitiensis (Echinodermata; Holothuroidea) in Hurghada area, Red Sea, Egypt. Egyptian Journal of Aquatic Research, 39(2), 115-123.

Pañola-Madrigal, A., Calderón-Aguilera, L. E., AguilarCruz, C. A., Reyes-Bonilla, H. \& Herrero-Pérezrul, M. D. (2017). Reproductive cycle of the sea cucumber (Isostichopus fuscus) and its relationship with oceanographic variables at its northern most distribution site. Revista de Biología Tropical, 66(1), 180-196.
Pérez, A. \& Marcos, C. (1985). Técnicas de recolección y estudio en la clase Holothuroidea. 1. Generalidades, sistemática, ecología, biología y comportamiento. Anales de biología, 3, 13-35.

Peters-Didier, J., Pardo, L. M., Garrido, O. \& Gallardo, C. S. (2018). Reproductive biology of the commercial sea cucumber Athyonidium chilensis (Holothuroidea: Dendrochirotida) in southern Chile. Journal of the Marine Biological Association of the United Kingdom, 98(2), 311-323.

Poh-Sze, J. (2004). Fisheries, trade and utilization of sea cucumbers in Malasya. In A. Lovatelli, C. Conand, S. Purcell, S. Uthicke, J. F. Hamel \& A. Mercier (Eds.), Advances in Sea Cucumber Aquaculture and Management (pp. 57-68). Rome, Italy: FAO Fisheries and Aquaculture Technical Paper, No. 463.

Purcell, S. W., Mercier, A., Conand, C., Hamel, J. F., ToralGranda, V., Lovatelli, A. \& Uthicke, S. (2013). Sea cucumber fisheries: global analysis of stocks, management measures and drivers of overfishing. Fish and Fisheries, 14(1), 34-59.

Rakaj, A., Fianchini, A., Boncagni, P., Lovatelli, A., Scardi, M. \& Cataudella, S. (2018). Spawning and rearing of Holothuria tubulosa: A new candidate for aquaculture in the Mediterranean region. Aquaculture Research, 49(1), 557-568.

Ramofafia, C., Battaglene, S. C., Bell, J. D. \& Byrne, M. (2000). Reproductive biology of the commercial sea cucumber Holothuria fuscogilva in the Solomon Islands. Marine Biology, 136(6), 1045-1056.

Ramofafia, C., Byrne, M. \& Battanglene, S. (2001). Reproductive biology of the intertidal sea cucumber Actinopyga mauritiana in the Solomon Islands. Marine Biology, 81(3), 523-531.

Santos, R., Dias, S., Pinteus, S., Silva, J., Alves, C., Tecelão, C., ... Pombo, A. (2016). Sea cucumber Holothuria forskali, a new resource for aquaculture? Reproductive biology and nutraceutical approach. Aquaculture research, 47(7), 2307-2323.

Sewell, M. A. (1992). Reproduction of the temperate aspidochirote Stichopus mollis (Echinodermata: Holothuroidea) in New Zealand. Ophelia, 35(2), 103-121.

Sewell, M. A. \& Bergquist, P. R. (1990). Variability in the reproductive cycle of Stichopus mollis (Echinodermata: Holothuroidea). Invertebrate Reproduction and Development, 17(1), 1-7.

Sewell, M. A., Tyler, P. A., Young, C. M. \& Conand, C. (1997). Ovarian development in the class Holothuroidea: a reassessment of the "Tubule recruitment model”. The Biological Bulletin, 192(1), 17-26.

Shiell, G. R. \& Uthicke, S. (2006). Reproduction of the commercial sea cucumber Holothuria whitmaei [Holothuroidea: Aspidochirotida] in the Indian and 
Pacific Ocean regions of Australia. Marine Biology, 148(5), 973-986.

Sonnenholzner, J. I., Searcy-Bernal, R. \& Panchana-Orrala M. (2017). The potential for propagation of the commercial sea cucumber Isostichopus fuscus (Ludwig, 1875 ) by induced transverse fission. Regional Studies in Marine Science, 9, 35-42.

Suárez, M. P., Álvarez, C., Molist, P. \& San Juan, F. (2005). Particular aspects of gonadal cycle and seasonal distribution of gametogenic stages of Mytilus galloprovincialis cultured in the estuary of Vigo. Journal of Shellfish Research, 24(2), 531-540.

Taboada, C., Millán, R. Míguez, I. \& Fernández-Pulpeiro, E. (2008). Composición en macronutrientes, aminoácidos y minerales de algunos invertebrados marinos no utilizados habitualmente como alimento. Revista Real Academia de Ciencias, 27, 95-106.

Tuwo, A. \& Conand, C. (1992). Reproductive biology of the holothurian Holothuria forskali (Echinodermata).
Journal of the Marine Biological Association of the United Kingdom, 720, 745-758.

Wen, J., Hu, C. \& Fan, S. (2010). Chemical composition and nutritional quality of sea cucumbers. Journal of the Science of Food Agriculture, 90, 2469-2474.

Wilcox, R. (2012). Introduction to Robust Estimation and Hypothesis Testing ( $3^{\text {rd }}$ Ed.). Elsevier.

Zhong, Y., Khan, M. A. \& Shahidi, F. (2007). Compositional characteristics and antioxidant properties of fresh and processed sea cucumber (Cucumaria frondosa). Journal of Agricultural and Food Chemistry, 55(4), 1188-1192.

Woong, H., Lee, C., Yoo, H. \& Hang, S. (2017). Reproductive cycle and realizing time for increase of resource of adult sea cucumber Aspotichopus japonicus released to seed breeding grounds. Animal cells and systems, 21(1), 53-62. 